\title{
Defending and Modelling Europe: The Visegrad Group Experience
}

\author{
Alexandru Trifu \\ $\mathrm{PhD}$, Professor, University "Petre Andrei” of Iasi, Romania
}

\section{Abstract}

In the world of today, the sole economic region with its own institutions (of a supra-state nature), with a coherent economic policy in every respect regarding the almost all European Space, is the European Union.

After the last wave on enlargement, Croatia in 2014 and the exit of United Kingdom in 2019 (the famous "Brexit"), with threats from external sources and with even home tensions amongst the 27 Mermber States, the EU needs cohesion and harmonization of different points of view, in order to ensure the functionality of all pieces and "parts" of the its complex economic and social system.

In this case, we consider that an import role can play so-called The Visegrad 4 or Visegrad Group - Hungary, Czech Republic, Slovakia and Poland, - on the one hand to defend the achievements of the EU, and on the other hand, to report shortcomings and to improve norms and regulations, favorable for all Members, as in the examples analyzed in the paper.

Therefore, we consider that is better to be a sort of counterweight to the global leadership of Bruxelles, in order to maintain the cohesion and a balanced development of the European Union.

Even some countries of the group have taken measures considered illiberal forms of democracy and, therefore, leading to euroscepticism, in fact their economies have hugely benefited from the absorption of EU funds.

The economic development and the existence of a sound economic infrastructure are the premises for a better understanding of the facts and realities in the European Union and allow to the respective country (countries) to have a grounded opinion and influence the general management of the Union.

Everyone has to think and understand the co-ordination between the local interests of the Member States and what the Regional system needs and intend to do. Exactly, this is the situation in the relationships between Leadership and Management.

In the last place, the V4 is supporting, by its experience, the integration of the West Balkans countries within EU and promoting the enlargement process as the most suitable tool of EU influence and image in the region.

Keywords: Visegrad 4, migrants, food double standard, cohesion, multispeed Europe.

JEL Classification: F15, R11.

(C) The Author, 2018. This article is published with open access at Sumy State University.

\section{The Visegrad Group (Visegrad 4) existence}

The reason to be of the Visegrad Four, established in 1991 and strengthened during the last decade, is to contribute effectively to the consolidation of the Eastern flank of EU, reinforcing co-operation in this area and to be an complementary institution (instrument) towards a balanced development and functioning of the community system.

This organization of countries reflects the efforts of the 4 (four) Member Countries - Hungary, Czech Republic, Slovakia and Poland - to work together in different fields of common interest within the whole European process of integration. The unity of the 4 consists in the sharing of the same cultural and intellectual values, common roots and the same religion, which they intend to preserve and, if it's possible, to strengthen them.

It must be understood that this organization was not created against the spirit of integration in the European Union, but to encourage co-operation in different domains and at different levels with all countries, in the spirit of democracy and of the development of all parts of our continent ${ }^{1}$.

The major interest is to combine the sub-region development and collaboration with the contribution to build the new European architecture, in security, co-operation and reasonable standard of life.

${ }^{1}$ See also *** www.visegradgroup.eu/about accessed May 8, 2018. 
The stability in Central and Eastern Europe, supported by these 4 (four) states, is benefic for the entire development and progress of the European Union. And this stability in the structure and quality of V4 is represented by the enhancing the values amongst them in the fields of culture, education, science and information.

The main decision and, we may say, the credo of the Visegrad Four, is the construction of "A Better Europe". This is the solution admitted by the four members at Warsaw, March 2201 7, as program to be presented (and presented) to the EU Summit in Rome, March 25.

But, if we are taking into account another scenario, another possibility of development and geometry for Europe, Slovakia, from all the four countries, being the only member of the Euro Zone, is not worried about the likelihood of the "Multispeed Europe", scenario which can gain perspectives in the next period.

Also, it can be affirmed that this organization is not in opposition with the community institutions and decisionmakers at the regional level (overstate one). Why this organization, this structure is considered functional and trustworthy? Because all the four countries, not only from the economic point of view (we saw the figures), but also from cultural, religious, education, exchanges of good and information points of view, are considered a single unit of civilization, with the same roots and traditions, desiring to strengthen these relationships in mutual advantages and in the benefit of the EU as a whole ${ }^{2}$.

As methodology, in this paper it was used the survey of the news and regarding this subject, positivism and deductive method, because it offers the possibility to generalize research survey or findings to a certain extent, for a better understanding of the facts.

\section{Protection for EU}

In fact, we are dealing with the migrants problem, a crisis which stroke the Europe from Middle East (in this analyzed case) and it is a potential factor of chaos.

In our case, it's about the route from Syria/Irak, Turkey/Greece, the Balkans, Serbia, Hungary (the majority of the migrants), Austria and final stop is Germany, or other Western countries. The problem is not the number of these migrants, hundreds of thousands, but the fact that, amongst them, terrorist could be infiltrated and try to destabilize the host communities.

Speaking about Germany, with its first step to permit "open borders" and the entrance of many migrants, especially from regions well-known for persecuting non-Muslims and bases for jihadist movements, this policy increased the vulnerabilities and dangers for entire Europe, not only for the Western countries.

Furthermore, in return, speaking about Visegrad 4, the four countries were accused from the Bruxelles officials for lack of "European Union Solidarity", by their refusal to accept imposed quotas of refugees of the migrants from Greece and Italy. But, an authorized analyst of this phenomenon said ${ }^{3}$ that this cliche was invented by some rulers from Bruxelles overhead Members and it is highly divisive.

Once again (and we'll see in the following pages facts of the V4 towards modelling Europe) these four countries refuse lectures and pressions from other leaders of Europe regarding preventive measures for this phenomenon, like in old times to stop the invasion of Europe by the Turks.

In order to solve this sensitive, but major problem, the leaders of the four countries have come up with concrete solutions to this:

1) The necessity to separate the economic and social migrants from the rest of the refugees.

2) Also, it is needed to provide secure camps for the refugees outside the EU. Health, social, humanitarian aids to protect the people who needs more of these aspects.

3) At the same time, to ensure assistance and funding to NGOs and other organizations in order to help refugees in integration into the new social and economic structures.

And there are many examples in the media of the implication and aid given by the four states in all area of war of the Middle East.

\footnotetext{
${ }^{2}$ See Trifu, Alexandru (2017). Visegrad Group: A “counterweight” within the EU system, in International Journal of Development and Sustainability, $6(10), 1232-1238$

${ }^{3}$ Ravotti, Bill (2017). Visegrad nations protect the EU. It's time to say "Thanks", updated 8. 12. 2017, www.euronews.com/2017 accessed 9.05.2018.
} 
Another aspect of it, that is the concerted efforts of the community towards securing borders from South-East and South of Europe. In this migration problem, the Visegrad 4 plus Austria, even Serbia, FYR of Macedonia, become really a counterweight to Germany, France and even European Parliament in preventing and reducing the pressure of migrants waves to the heart of Europe.

Some of the political analysts, amongst them Bill Ravotti, me also, opine that such structure as the Visegrad 4, an operative managerial unit, represent a model for the future of the European Union, of the European architecture.

Speaking abourt the defence of Europe, we'd like to highlight another aspect of it, the existence of the Common Security and Defence Policy (CSDP) which enables the EU to take a leading role in peace-keeping operations, conflict prevention and in strenghtening the international security. It is a part of EU's comprehensive approach towards crisis management (our emphasis) ${ }^{4}$.

For the members of V4, this CSDP is considered as inefficient being necessary more discussion between Member States (the last one was recently, at the beginning of May), in order to gain strategic independence, mainly in confrontation with US policy and doctrine in the field. In our case, on average of $62 \%$ of respondents from these countries think that EU has to be more strategically independent from US and that the European Defence Fund will prove effective in pratice in enhancing the EU defence capabilities ${ }^{5}$. Some of the people of Czech Republic think that this strategic autonomus must be the highest possible level.

In the following representation, we see the distribution of answers to the questions posed in the four countries of the group:

We see that, despite the expectations on CSDP at a high level, on, only $39 \%$ of the Visegrad Group respondents expect that fact, but a large number of respondents sustain the existence in the next years of this policy and see the possibility to co-existence between Europe and US in this respect (especially answer to the question 2).

CSDP OF THE EU

TO WHAT EXTENT DO YOU AGREE WITH THE FOLLOWING PROPOSITIONS ABOUT THE CSDP OF THE EU? [ $\mathrm{V} 4$ average]

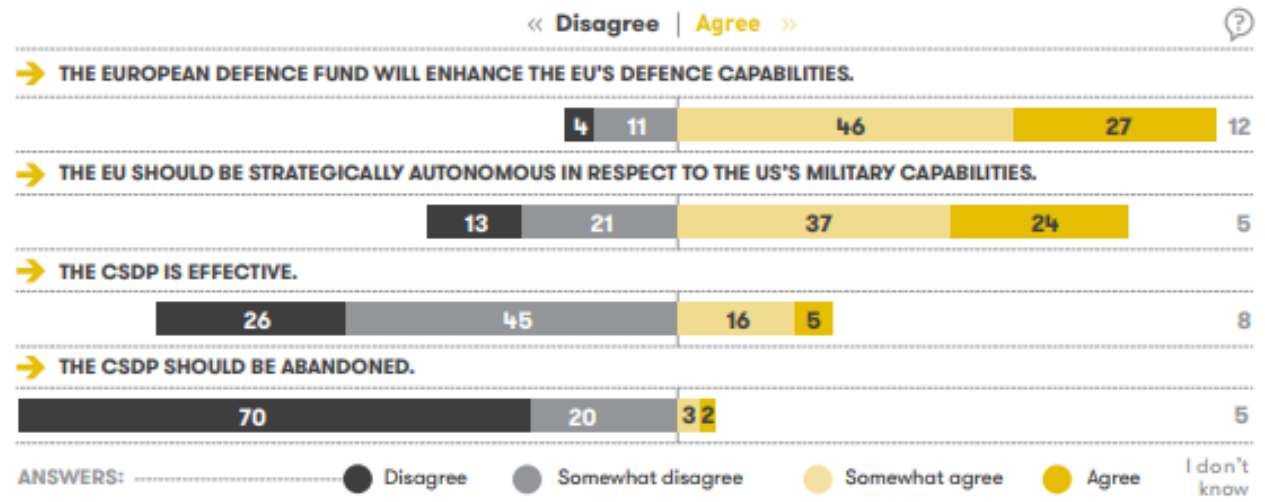

Figure 1. Common Security and Defence Policy of the Eutopean Union

Source: http://www.ejsnews.com November 27, 2017.

\section{Economic modelling of EU}

We may say that the V4 countries have benefited hugely from the EU subdisies and funds (Poland is leader with almost $100 \%$ absorption of community funds).

In this part, we intend to highlight only the results of pression of Visegrad Group over European Comission regarding the existence of double standard between the same products, or similar, delivered on Western market and those retailed on the Central and Eastern markets.

\footnotetext{
4 *** (2018). The Common Security and Defence Policy (CSDP), www.eeas.europa.eu/topics accessed May 10, 2018.

${ }^{5}$ Dostal, Vit, Vegh, Zsuzsanna (2017). For Visegrad, CSDP is ineffective, but EU should gain strategic independence. In European Security Journal, November, www.esjnews.com, accessed May 11, 2018.
} 
This problem has started in July 2017, when EC offered to pay different studies for those Member States which believed in the existence of a "dual food quality"6.

Technically speaking, there were two categories of dual food quality possible: a. The different quantity of the main constituent in the final package (a misleading of the label used); $b$. The same product in West and East has a lower quality in the latter case.

April 112018 was an important day for the Community, because European Commission recognises the fact revealed by the Visegrad 4 and ban the difference of quality level for brand products depending on their destination market. The products from Central and Eastern countries were in reality of a lower quality than the same products on Western markets ${ }^{7}$. It is about the double quality level of food and unfair commercial practices. Along with the V4 countries was also Bulgaria, whose Prime-Minister declared, too hard, maybe, that it was a "food apartheid".

But the merit of the final success of the Visegrad Group is due,, in a large measure, to the politic involvment by Slovakian Prime-Minister Robert Fico, considered a leader in the organization structure which is V4 and who convinced Jean-Claude Juncker of the justice of the claims.

\section{Possible Leadership and Management Resemblance}

The revealed situation and the realities of European Community show us a possible translation to the terms of Leader and Manager. In fact, the important key factor in any entity, is the CEO. Specifically, the Leader is EU and Manager is Visegrad 4, like in a firm, corporation, where it is an important department or structure, vital for the well-functioning of the whole system.

The managerial studies reveal that the CEOs-leaders are more efficient than the CEOs-managers, especially in great organizations, corporation and where it's about of financial strategies and policies to be followed. In our specific case, yes, Bruxelles (HQ of EU) is considered a Leader, for its vision, for the discussions with all parts involved in, for general strategic lines. On the other hand, the Manager can be considered Visegrad 4 collective management, which is focused on the specific tactics, tasks, and functioning of the "department" called Visegrad Group.

For example, Bruxelles has to listen, as a Leader of $E U$, the solutions and measures proposed by some Member States, such as the Visegrad Group, in the problem of migration, of double standard of food products and other structural issue of the community.

It is needed of ideas to be put in practice, rational discussions with all members and all parts involved in solving different shortcomings and failures in the functioning of the European unique and complex system.

In order to improve the regional organizational leadership, it is advisable to get a balance between the orientation and directives towards results and the orientation towards the means and instruments to obtain them. And, the late comprises the solutions and pratical ideas of the Visegrad Group within the larger system of EU.

Furthermore, the analysis, but merely the pressions came from V4, were done to identify the causes and factors of dissatisfaction and claims regarding the necessary corrections and improvements of different aspects of community life and economy.

The fears for the European Union is the possible clash between the different concepts and points of view from the Western countries and those of the Central and Eastern Countries. To certain extent, the fear is true, but exactly as in a firm, organization, measures must be taken in possible divergences ${ }^{8}$.

The V4 also agreed in the benefits of a continued economic integration. The particulars and general scopes have to continue to be achieved in good terms ${ }^{9}$.

Furthermore, the analysts observe, however, a beginning of division inside the group, i.e. Poland and Hungary, from one side, prepared to several replies against Bruxelles and Czech Republic and Slovakia, on the other side, regarding the influence and constructiveness in the EU. Hence, the necessity that also this part of the system to be functioning in a manner to harmonize the interests.

\footnotetext{
${ }^{6}$ See Teffer, Peter (2017). Visegrad lobby makes food quality an ERU issue, www.eurobserver.com, accessed May $13,2018$.

7 *** (2018). Victory for the V4: the European Union bans double quality of brand products, www.visegradpost.com/en, accessed May 10, 2018.

${ }^{8}$ Adler, Katy (2018). Visegrad: the clash of the euro visions, www.bbc.com/news accessed May, 12, 2018.

${ }^{9}$ Singer, Miroslav (2018). EU risks in Visegrad Group, www.omfif.org/analysis accessed May 13, 2018.
} 
In order to increase its international competitiveness, each country from $\mathbf{V} 4$ should follow the pattern of the country which stands above it (in the competitiveness ranking but, at the same time, is the most similar. In this latter case, the case of Poland could be a proper solution.

\section{Conclusions}

The victory in so-called food discrimination products is considered a success for all Central and Eastern countries and prove that Visegrad Group is capable to make pressure on the European Comission, in order to invoke the rights of its member and based on pertinent observations.

The leaders must know exactly what the organization want, what are its needs and, hence, what skills and abilities CEOs-leaders and CEOs-managers should have to combine the interests of the parts, of the entity (corporation, firm, organization) with those of the environment.

Therefore, in our case, we consider that the feedback of the Visegrad Group in some sensitive and relevant issues of our days to the directives and norms came from Bruxelles and, closing the circle, the understanding by the EU leaders of these mistakes and failures, means a successful interaction leadership-management, strategies-tactics.

Also, we consider that the leader should provide feedback immediately after the member parts claims or actions for a clearer understanding of the issue and to avoid repeating mistakes or failures (see the action of Jean Claude Juncker regarding the double food standard issue).

If the actual trends will continue, the four countries of the Visegrad Group will enjoy positive economic and social developments and by their critique in some issue, they'll become a factor of correction and stability of the European Union.

Even from inside the group, it is the perception that, in order to improve their position as a whole, the $\mathbf{V 4}$ needs to provide more colourful image, a positive one, not just different shades of grey.

It is a functional organization entity, a "voice" for the smaller or less developed economies of the European Union, in order to adjust some decisions or facts provided by the inter-states relationships, but in no case it's about a bipolar situation, i.e. more decisional centers for the EU.

\section{References}

1. Adler, Katya (2018). Visegrad: The clash of the euro visions. Retrieved from: www.bbc.com/news (accesed May12, 2018).

2. Avramescu, T.C. (2009). Economie Europeana (European Economy). Sitech Publishers, Craiova.

3. Dostal, Vit, Vegh, Zsuzsanna (2017). For Visegrad, CSDP is ineffective, but EU should gain strategic independence, in European Security Journal, November. Retrieved from: www.esjnews.com (accessed May 11, 2018).

4. Judt, Tony (2011). A Grand Illusion? An Essay on Europe. New York University Press.

5. Milea, Oana Maria (2014). Economie Europeana (European Economy). Universitara Publishers, Bucharest.

6. Panke, Diana (2016). Small States in the European Union: Coping with Structural Disadvantages. Routledge.

7. Ravotti, Bill (2017). Visegrad nations protect the EU. It's time to say "Thanks". Retrieved from: www.euronews.com/2017 (accessed May 9, 2018).

8. Singer, Miroslav (2018). EU risks in Visegrad Group. Retrieved from: www.omfif.org/analysis (accessed May 13, 2018)

9. Staab, Andreas (2013). European Union Explained: Institutions, Actors, Global Impact. $3^{\text {rd }}$ edition, Indiana University Press.

10. Teffer, Peter (2017). Visegrad lobby makes food quality an EU issue. Retrieved from: www.eurobserver.com (accessed May 13, 2018).

11. Trifu, Alexandru (2017). Visegrad Group: A “counterweight” within the EU system. International Journal for Development and Sustainability, 6(10), pp. 1232-1238.

12. *** (2018). The Common Security and Defence Policy (CSDP). Retrieved from: www.eeas.europa.eu/topics (accessed May 10, 2018).

13. *** (2018). Victory for the V4: the European Union bans double quality of brand products. Retrieved from: www.visegradpost.com/en (accessed May 10, 2018). 
14. $* * *$ Eurostat data. Retrieved from: www.ec.europa.eu/eurostat/web/population-demography-migrationprojections/ (accessed May 8, 2018).

15. *** (2018). Victory for V4: the European Union bans double quality of brand products. Retrieved from: www.visegradpost.com/en (accessed May 10, 2018). 